\title{
Biji kopi meningkatkan ekspresi glutathione pada monosit secara in vitro (Coffee beans increase glutathione expression to monocyes in vitro)
}

\author{
Roedy Budirahardjo \\ Bagian Pedodontik \\ Fakultas Kedokteran Gigi Universitas Jember \\ Jember, Indonesia
}

\begin{abstract}
Some research stated that coffee may act as an antioxidant, but has not mentioned concentrations can distinguish the production of antioxidants. One of the important antioxidant roles in preventing various diseases is GSH. The research is intended to analyze the expression of antioxidant GSH of coffee beans in vitro. Furthermore, the culture of peripheral blood monocytes of healthy people as much as $6 c c$, mixed with the anticoagulant heparin. Ficoll-Hypaque centrifugation and suspended in RPMI 1640 medium Buffy coat separated, washed, resuspended. Cells were placed on plate 96-well microtiter of $8 \times 105$ cells/well, and incubated. Then added RPMI, incubated and lymphocytes discarded. After washing, complete medium was added and incubation. Monocytes reacted with coffee with various concentrations (4 groups) and incubated 18 hours. GSH then analyzed by immunocytochemistry method. GSH cells expressing brown and counted under a light microscope (400x). The results indicated that a concentration of $3 \mathrm{~g}$ coffee brewed in $300 \mathrm{~mL}$ of hot water has the greatest ability to increase GSH. It was concluded that coffee can improve GSH expression on monocytes were exposed to DMBA, and the higher the concentration of the coffee bean, the higher the expression of GSH.
\end{abstract}

Keywords: coffee, GSH, antioxidant, immunocytochemistry

\begin{abstract}
ABSTRAK
Beberapa penelitan menyebutkan bahwa kopi dapat berperan sebagai antioksidan, tetapi belum disebutkan konsentrasi yang dapat membedakan produksi antioksidan. Salah satu antioksidan yang penting perannya dalam mencegah berbagai macam penyakit adalah GSH. Penelitian dimaksudkan untuk menganalisis ekspresi antioksidan GSH dari biji kopi secara in vitro. Selanjutnya dilakukan kultur monosit darah perifer orang sehat sebanyak 6 cc, kemudian dicampur dengan antikoagulan heparin. Ficoll-hypaque centrifugation dan disuspensi dalam media RPMI 1640. Buffy coat dipisah, dicuci, diresuspensi. Sel ditempatkan pada plat titer mikro $96-w e l l ~ 8 \times 10^{5} \mathrm{sel} / \mathrm{well}$, dan diinkubasi. Selanjutnya ditambahkan RPMI, diinkubasi dan limfosit dibuang. Setelah dicuci, ditambahkan médium komplit dan inkubasi. Monosit direaksikan dengan kopi dengan berbagai konsentrasi dan diinkubasi 18 jam. Selanjutnya GSH dianalisis dengan metode imunositokimia. Sel yang mengekspresikan GSH berwarna coklat dan dihitung di bawah mikroskop cahaya (400x). Sampel dikelompokkan menjadi 4 kelompok, yaitu kontrol dan 3 konsentrasi kopi. Ditunjukkan hasil bahwa kopi dengan konsentrasi $3 \mathrm{~g}$ yang diseduh dalam air panas $300 \mathrm{~mL}$ memiliki kemampuan yang paling besar dalam meningkatkan GSH. Disimpulkan bahwa kopi dapat meningkatkan ekspresi GSH pada monosit yang dipapar DMBA, dan semakin tinggi konsentrasi biji kopi maka semakin tinggi ekspresi GSH.
\end{abstract}

Kata kunci: kopi, GSH, antioksidan, imunositokimia

Koresponden: Roedy Budirahardjo, Jl. Kalimantan No.37, Jember, Indonesia. E-mail: roedibudirahardjo@yahoo.com

\section{PENDAHULUAN}

Tanaman kopi merupakan komoditi eksporyang cukup menguntungkan sebab memiliki arti ekonomis yang relatif tinggi di pasaran dunia. Di samping itu tanaman kopi adalah salah satu komoditas unggulan yang dikembangkan di Jember. Kandungan kimia kopi seperti flavonoid, xanthine, antioksidan, dan alkaloid dapat berfungsi sebagai anti-inflamasi, anti bakteri, antikanker. ${ }^{1-4}$ Hambatan kopi terhadap $S$. mutan dihitung pada media pertumbuhan, ${ }^{5}$ oleh sebab itu diharapkan kopi dapat memberi solusi sebagai pencegah kanker rongga mulut yang harganya murah, mudah diperoleh dan efektif. Sedangkan proteksi anti oksidan dapat dilakukan dengan menganalisis rasio antioksidan seperti GSH/GSSG (gluthathione), Gpx (gluthathione peroxidase) dan GST (gluthathione stransferase). ${ }^{6}$ Sedangkan marker untuk proliferasi dan diferensiasi sel kanker dapat diketahui melalui adanya proliferating cell nuclear antigen(PCNA) dan p53.,

Program nasional untuk menemukan obat baru dari sumber bahan alam sekarang ini menggunakan paradigmabaru, yaitu menggabungkan dua kekuatan sumber daya raksasa yang ada, yaitu sumber alam hayati di Indonesia dengan hasil-hasil riset dunia mengenai genom manusia atau genom lainnya, dan akhirnya akan diperoleh senyawa penuntun atau lead 
compound untuk dikembangkan menjadi suatu obat baru. ${ }^{9,10}$

Berdasarkan pemahaman untuk mendapatkan obat baru, pada penelitian ini dianalisis ekspresi anti oksidan GSH dari biji kopi secara in vitro.

\section{BAHAN DAN METODE}

Dilakukan pengambilan darah perifer orang sehat sebanyak $6 \mathrm{cc}$, kemudian dicampur dengan antikoagulan heparin, lalu sentrifugasi dengan ficollhypaque centrifugation dan disuspensi dalam media RPMI 1640. Sel ditempatkan pada plat titer mikro 96-well $8 \times 10^{5} \mathrm{sel} /$ well selama 45 menit $37^{\circ} \mathrm{C}$ dan dicuci empat kali dengan media. Sel yang melekat adalahmonosit. Beberapa well ditripsinasi dan secara hati-hati dikerok untuk keperluan penghitungan sel sehingga dihasilkan 1-2 × $10^{5}$ monosit/well. Monosit yang melekat diinkubasi selama 7-10 hari dalam 200 $\mu \mathrm{L}$ RPMI 1640 yang diperkaya dengan 10\% FBS (BioWhittaker, Walkersville, MD), $25 \mathrm{~mL}$ HEPES buffer, $50 \mu \mathrm{g}$ vancomisin, dan $10 \mu \mathrm{g} / \mathrm{mL}$ gentamisin sebelum digunakan. Selanjutnya monosit dilapiskan pada well kemudian diinkubasi dengan 2 cc RPMI dan ditambah kopi $2 \mathrm{~mL}$ semalam. Sebelum inkubasi selama 18 jam,monositdireaksikan dengan beberapa konsentrasi kopi, yaitu K0: monosit, K1: monosit + kopi A (3 g dalam $300 \mathrm{~mL}$ akuades), K2: monosit + kopi B (3 g kopi dalam $600 \mathrm{~mL}$ akuades), K3: monosit + kopi C (3 g kopi dalam $1200 \mathrm{~mL}$ akuades). Berikut GSH dianalisis dengan metode imunositokimia, yaitu direaksikan dengan anti-GSH. Sel yang digunakan mengekspresikan GSH adalah yangberwarna coklat dan dihitung di bawah mikroskop cahaya dengan pembesaran 400x, selanjutnya dilakukan pengecatan imunositokimia.

\section{Metode imunositokimia untuk analisis ekspresi GSH}

Sediaan preparat digenangi larutan $\mathrm{H}_{2} \mathrm{O}_{2} 3 \%$, lalu dicuci dengan PBS $2 \mathrm{x}$ dan dilakukan proses bloking dengan BSA 3\%.Antihuman GSH diinkubasi selama 24 jampada suhu $4^{0} \mathrm{C}$ dalam humidity chamber, direaksikan dengan biotiyilized secondary $\mathrm{Ab}$, lalu dicuci $3 x$ dengan PBS, dan ditambahkan streptavidin berlabel peroksidase dan diinkubasi selama 1 jam. Selanjutnya, dilakukan pencucian kembali dengan PBS sebanyak 3 kali, direaksikan dengan substrat diamine benzidine (DAB), kemudian ditambahkan "Meyer-HE". Lalu sel yang mengekspresikan GSH berwarna coklat di bawah mikroskop cahaya dengan pembesaran 400 kali dan dihitung pada lima lapang pandang.

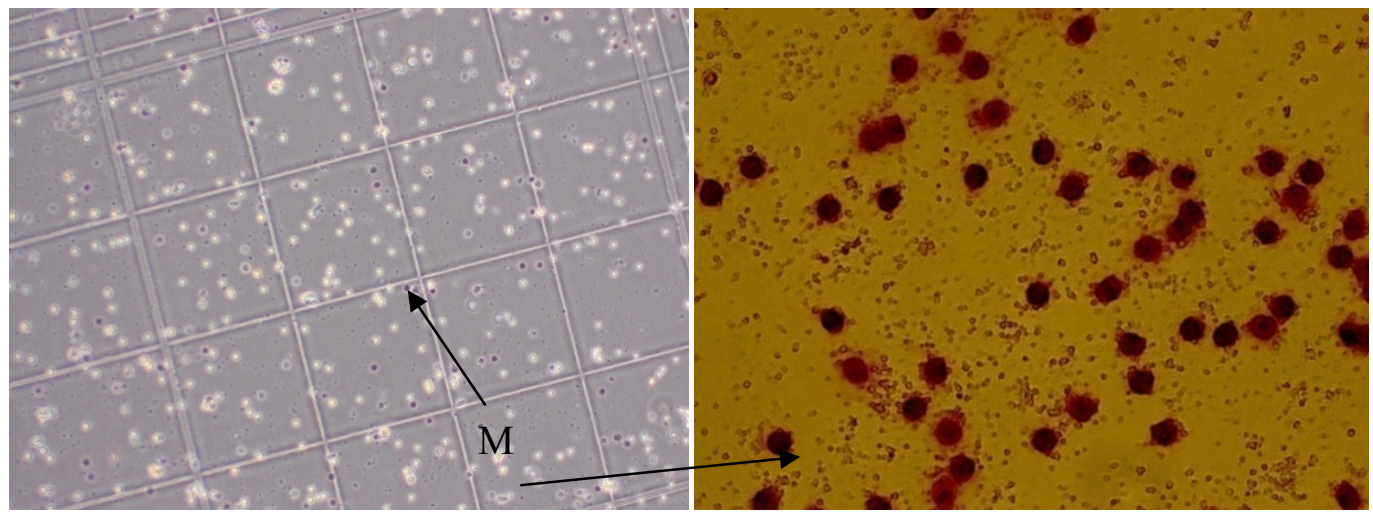

Gambar 1 Hasil Isolasi dan kultur monosit (tanda panah)
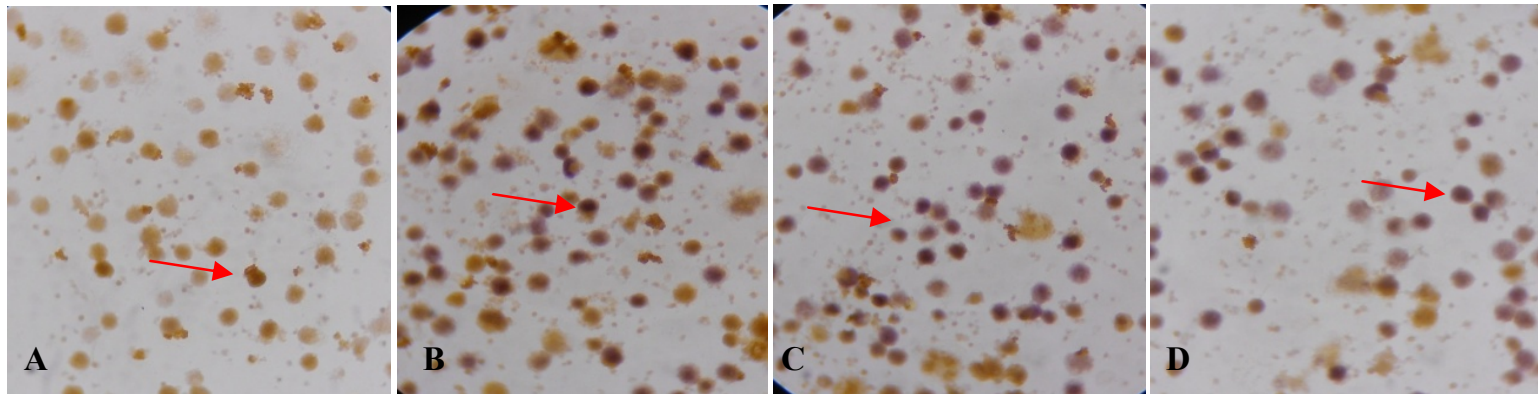

Gambar 2 Hasil penelitian (mikrokop cahaya pembesaran 400x). Sel dengan warna coklat adalah (tanda panah) yang mengekspresikan GSH 


\section{HASIL}

Data penelitian terdistribusi normal menurut Kosmogorov Smirnov dan homogen berdasarkan uji Lavene ( $\mathrm{p}>0,05)$. Uji anova $(\mathrm{p}<0,01)$ menunjukkan terdapat perbedaan yang bermakna pada seluruh kelompok. Selanjutnya dengan uji LSD $(\mathrm{p}<0,05)$, tampak perbedaan yang bermakna antara $\mathrm{K} 0$ dengan semua kelompok perlakuan, antara K1 dengan K2, antara $\mathrm{K} 1$ dengan $\mathrm{K} 3$, antara $\mathrm{K} 2$ dengan $\mathrm{K} 3$.

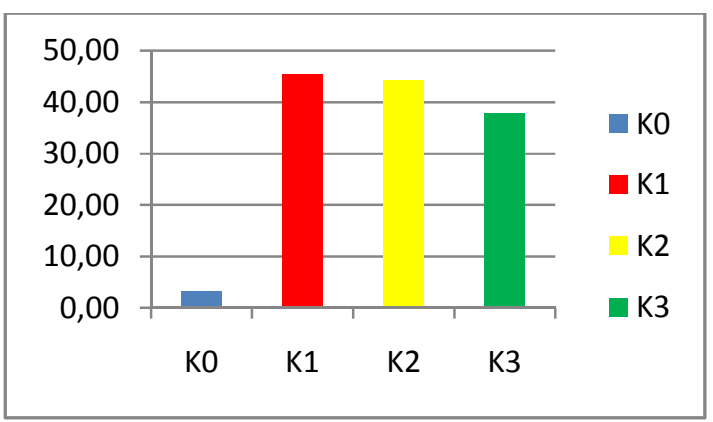

Gambar 2 Diagram batang ekspresi GSH pada monosit akibat paparan kopi dan DMBA

Pada gambar 2 terlihat bahwa Ko memiliki tinggi batangpalingrendah, artinya ekspresiGSH-nya paling sedikit. Sementara K1 memiliki batang tertinggi, artinya ekspresi GSH kelompok K1 (monosit + kopi A+DMBA) memiliki kemampuan mengekspresikan GSH yang paling besar. Disimpulkan bahwa semakin rendah konsentrasi kopi, makin kecil ekspresi GSH.

\section{PEMBAHASAN}

Dari hasil penelitian, terlihat bahwa kopi dapat meningkatkan ekspresi GSH pada monosit. Hal ini diduga karena kopi akan ditangkap oleh reseptor monosit, kemudian mempengaruhi aktivitas protein transkripsi dalam sel. Protein-protein transkripsi akan menentukan atau mempengaruhigen-gen pembentuk GSH. Peningkatan GSH oleh monosit juga terlihat pada paparan dengan DMBA. Hal ini menunujukkan bahwa kopi mampu meningkatkan aktivitas monosit dalam menghasilkan GSH ketika ada paparan bahan karsinogenik, selain berguna sebagai kemoprevensi. Kandungan aktif dalam kopi yang diduga sebagai antioksidan, misalnya polifenol dan alkaloid. Potensi kopi untuk meningkatkan GSH dan aktivitas GST dalam hati tikus diamati oleh Abraham dan Singh, yang menyatakan bahwa konstituen kopi, selain kafein ditandai efek antikarsinogenik kopi, hasilnya menegaskan pentingnya kopi sebagai pencegahan karsinogenesis di lingkungan. ${ }^{11}$ Diduga peningkatan GSH terhubung dengan senyawa fenolik dalam kopi. Kemungkinan bahwa parameter fundamental, seperti konsentrasi GSH atau kegiatan GST, terkait dengan asupan kopi.Selain itu diduga kopi juga mengandung diterpenes bioaktif, yang menyebabkan peningkatan konsentrasi homosistein plasma. Sedikit peningkatan homosistein plasma juga disebabkan oleh jumlah besar kopi yang disaring.

GSH telah diidentifikasi sebagai agen antiinflamasi dalam sel yang merupakan antioksidan alami tubuh. Tingkat GSH yang tinggi bekerja untuk memerangi kerusakan tingkat oksidatif, mencegah perkembangan peradangan lebih lanjut, danrasa sakit yang dihasilkan. Sel akan diserang oleh tingginya tingkat stres oksidatif yang dihasilkan oleh suatu penyakit, jadi diperlukan GSH untuk melawannya, yang dapat ditemukan dalam setiap sel. GSH dapat memodulasi sistem kekebalan tubuh, memperlambat peradangan lebih lanjut dan meminimalkan efek samping dari obat penghilang rasa sakit. Dengan modulasi sistem kekebalan tubuh, GSH memiliki peran tertentu dalam mengurangi efek inflamasi yang menyakitkan. GSH merupakan protein kecil dan bagian dari komponen penting dari sistem kekebalan tubuh kita. Zat ini diproduksi secara alami oleh selsel di seluruh tubuh, dan berperan penting sebagai antioksidan yang merupakan komponen terpenting dalam sistem kekebalan. Glutathione-S-transferase, merupakan katalis enzim, yang secara luar biasa dapat menangkap radikal bebas. Glutathione memiliki cabang yang disebut sulfhidril, yang dapat menyerap banyak elektrofil, sehingga membuatnya memiliki kemampuan serap yang besar.

Kopi memiliki antioksidan yang sangat tinggi aktivitasnya yang diduga karena adanya melanoidins dan senyawa fenolik, yang mungkin bertanggung jawab untuk dan efek antimutagenik, antigenotoksik kopi. Melanoidins yang terbentuk melalui reaksi maillard antara protein dan karbohidrat, sebagian besar hadir dalam kopi dan merupakan komponen utama minuman kopi (hingga 30\% dari bahan kering). Hal ini memiliki polisakarida yang berfungsi sebagai pembawa beberapa kelompok komponen bioaktif yang potensia, seperti cincin fenolik, reductones dan radikal. GSH dalam sel bertindak sebagai inhibitor dari karsinogenesis. ${ }^{11}$

Daripenelitian ini, disimpulkanbahwakopi dapat meningkatkan ekspresi dari GSH pada monosit yang dipapar DMBA. Kopi dengan konsentrasi $3 \mathrm{~g}$ yang diseduh air panas $300 \mathrm{~mL}$ memiliki kemampuan yang paling besar dalam meningkatkan GSH, sehingga dinyatakan bahwa semakin tinggi konsentrasi biji kopi maka semakin tinggi ekspresi GSH. 


\section{DAFTAR PUSTAKA}

1. Ashihara H. Metabolism of alkaloids in coffee plants. Braz J Plant Physiol 2006; 18(1)

2. Simanihuruk K, Sirait J. Silase kulit buah kopi sebagai pakan dasar pada kambing boerka sedang tumbuh (coffee pulp silages as basal feed for boerka goats on growth phase). Seminar nasional teknologi peternakan dan veteriner 2010

3. Naziq A. 12 Manfaat kopi bagi kesehatan, 8 Juli 2012

4. Arnaud HC. Green coffee extract has health benefits. Science \& Technology Concentrate 2013; 91(15):20-1

5. Namboodiripad P, Srividya K. Can coffee prevent caries? An in vitro study. Internet J Dent Sci 2009; 7(2). DOI: $10.5580 / 101 \mathrm{c}$

6. Mukherjee PK, Maiti K, Mukherjee K, Houghton PJ. Leads from Indian medicinal plants with hypoglycemic potentials. J Ethnopharmacol 2006; 106: 1-28

7. Scalbert A, Williamson G. Dietary intake and bioavailability of polyphenols. J Nutr 2000; 130 (8): 2073S-85S

8. Dupas CJ, Marsset-Baglieri AC, Ordonaud CS, Ducept FMG, Maillard MN. Coffee antioxidant properties: effects of milk addition and processing conditions. J Food Sci 2006; 71(3): S253-S8

9. Rajamanickam S, Ramasamy K, Siddavaram N. Expression of PCNA, cytokeratin, Bcl-2, and p53 during chemoprevention of hamster buccal pouch by ethanolic neem leaf axtract. Clin Biochem 2006; 39: 1080-7

10. Sudoyo H. Pendekatan biomolekuler untuk penemuan obat baru dari sumber daya alam dalam perspektif Indonesia. Cermin Dunia Farmasi 1997; 31: 9-11

11. Wahyuningsih MSH, Mubarika S, Gandjar IG, Wahyuono S. Pencarian senyawa antikanker dari bahan alam. Majalah Obat Tradisional 2003; 8(26): 9-11

12. Natella F, Nardini M, Belelli F, Pignatelli P, Di Santo S, Ghiselli A, Violi F, Scaccini C. Effect of coffee drinking on platelets: inhibition of aggregation and phenols incorporation. Br J Nutr 2008; 100(6):1276-82. doi: 10. 1017/S0007114508981459. Epub 2008 Apr 28

13. Sithisarn P, Subaphol R, Gritsanapan W. Antioxidant activity of Siamese neem tree. J Ethnoparmacol 2005; 99(1): 109-12

14. Esposito FF, Morisco V, Ritieni VA, Alezio A, Caporaso N, Fogliano V. Moderate coffee consumption increases plasma glutathione but not homocysteine in healthy subjects. Article first published online: 5 Mar 2003, DOI: 10.1046/j.1365-2036.2003.01429.x 